\title{
Pyrazinamide-induced Polyarthralgia and Myalgia in a Case of Stable Chronic Kidney Disease
}

\author{
Bijoy Kumar Panda', Vaibhav Rajendra Suryawanshi', Medha Bargaje ${ }^{2}$, Sathiyanarayanan L $^{3, *}$ \\ ${ }^{1}$ Department of Clinical Pharmacy, Poona College of Pharmacy, Bharati Vidyapeeth (Deemed to be University), Erandwane, \\ Pune, Maharashtra, INDIA. \\ ${ }^{2}$ Department of Pulmonary Medicine, Bharati Vidyapeeth (Deemed to be University) Medical College and Hospital, Pune, \\ Maharashtra, INDIA. \\ ${ }^{3}$ Department of Pharmaceutical Chemistry, Poona College of Pharmacy, Bharati Vidyapeeth (Deemed to be University), \\ Erandwane, Pune, Maharashtra, INDIA.
}

\begin{abstract}
Pyrazinamide is known to cause hyperuricemia and is followed by gout arthritis. But the fate of this drug in chronic kidney disease (CKD) patients is still not explored in details yet. We report a case of a 65-year-old Asian-Indian woman who was diagnosed with stable CKD 5 years ago and is currently diagnosed with peritoneal tuberculosis with pleural effusion. She was started on antitubercular therapy (ATT). On the 11 th day of ATT, she developed a rise in uric acid (from $7.2 \mathrm{mg} / \mathrm{dL}$ to $13.1 \mathrm{mg} / \mathrm{dL}$ ) and creatine kinase levels (from $156 \mathrm{U} / \mathrm{L}$ to $887 \mathrm{U} / \mathrm{L}$ ), followed by polyarthralgia and generalised myalgia on investigation. Her elevated uric acid and creatine kinase levels and polyarthralgia improved on cessation of pyrazinamide, but improvement in her myalgia and muscle weakness was postponed. Pyrazinamide plasma $2 \mathrm{hr}$ levels post dose was performed suspecting polyarthralgia and myalgia as an adverse drug reaction and estimated to be $59 \mu \mathrm{g} / \mathrm{ml}$ (normal range: 20-50 $\mu \mathrm{g} / \mathrm{ml}$ ). Subjective and objective assessments along with pyrazinamide plasma levels may be an indicative evidence of the adverse reaction as the estimated plasma concentration at $2 \mathrm{hr}$ was higher than the normal range.
\end{abstract}

Key words: Pyrazinamide, Polyarthralgia, Myalgia, Stable chronic kidney disease, Plasma levels.

\section{BACKGROUND}

Renal impaired patients did not show any significant differences in pharmacokinetics of pyrazinamide and pyrazinoic acid compared to normal patients, however higher levels and reduced metabolism of pyrazinamide was observed in patients with renal failure. This is due to accumulation or delayed elimination of pyrazinamide. ${ }^{1,2}$ Dosage adjustments and therapeutic drug monitoring (TDM) found to be useful in such patients, where monitoring of plasma concentration for 2 to $6 \mathrm{hr}$ after administration has been recommended. ${ }^{3,4}$ We present a case of pyrazinamide-induced polyarthralgia and myalgia in a stable chronic kidney disease (CKD) patient, where plasma levels of pyrazinamide were estimated.

\section{CASE PRESENTATION}

A 65-year-old Asian-Indian woman weighing 45-kgs with a known case of ischemic heart disease and stable chronic kidney disease for over 5 years presented to Pulmonary Medicine OPD of Bharati Hospital and Research Center, Pune with complaints of abdominal pain (periumbilical region), breathlessness, and reduced appetite since 15-days, weight loss (10-15 kg since 2-3 months). She had no history of fever, cough, cold or sore throat. She had a temperature of $38.2^{\circ} \mathrm{C}$ with a sinus pulse of $96 / \mathrm{min}$
DOI: 10.5530/ijopp.15.1.10

Address for correspondence: Dr. Sathiyanarayanan L, Associate Professor, Department of Pharmaceutical Chemistry, Poona College of Pharmacy, Bharati Vidyapeeth (Deemed to be) University, Pune-411046, Maharashtra State, INDIA.

Email id: I.satyanarayan@ bharatividyapeeth.edu

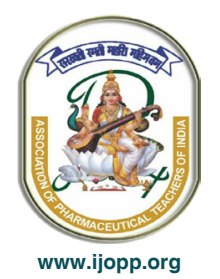


and blood pressure of 125/84 mm Hg. Her respiratory rate was 19 breaths per minute and her peripheral oxygen saturation was found to be $98 \%$ inspiring room air. On chest examination, percussions were noted with reduced bilateral air entry $(\mathrm{R}>\mathrm{L})$. Abdominal examination revealed distention and tenderness with ascites and abdominal guarding. She was admitted to the general medicine ward for further investigations. Her baseline serum creatinine (SCr), serum uric acid (SUA), and serum creatine kinase (CK) were within normal limits as shown in Table 1 . Troponin I, complete blood count and liver function tests were within normal limits. 2D-echo showed mild distal septum, hypokinetic anterior wall, moderate left ventricular (LV) systolic dysfunction, grade-I LV diastolic dysfunction, degenerative valve changes, mild aortic regurgitation, tricuspid regurgitation and left ventricular ejection factor of 35-40\% (normal range - 60-65\%). Her previous peroral medications were continued, including atorvastatin 40 $\mathrm{mg} / \mathrm{d}$, spironolactone $25 \mathrm{mg} / \mathrm{d}$, febuxostat $40 \mathrm{mg} / \mathrm{d}$, aspirin $75 \mathrm{mg} / \mathrm{d}$, as well as paracetamol $500 \mathrm{mg}$ three times a day, IV ceftriaxone $2 \mathrm{~g} / \mathrm{d}$, pantoprazole $40 \mathrm{mg} / \mathrm{d}$, vitamin B-complex, and protein powder. Ascitic fluid analysis and Gene-Xpert were performed to rule out extra-pulmonary tuberculosis. Proteins, lymphocytes, adenosine deaminase, and serum ascites albumin gradient (SAAG) was found to be deranged, which was suggestive of tubercular exudate (Table 1), though GeneXpert was found to be negative. ATT was not initiated at this stage.

On day-5, her fever $\left(38.4^{\circ} \mathrm{C}\right)$, cough, and generalised weakness were not resolved. Thoracentesis was performed, pleural fluid was sent for analysis and Gene-Xpert for tuberculosis as differential diagnosis. Proteins, lymphocytes, adenosine deaminase, and serum effusion albumin gradient (SAG) were found to be deranged, which was suggestive of tubercular transudate (Table 1). The Gene-Xpert and tuberculin test was found to be negative. Her chest X-ray showed exudative tubercular effusion $(\mathrm{R}>\mathrm{L})$. Suspecting peritoneal tuberculosis with pleural effusion, the patient was started with empirical anti-tubercular therapy (ATT) containing RCINEX ${ }^{\circledR}$ (rifampicin/isoniazid: $450 / 300 \mathrm{mg} / \mathrm{d}$ ), Combutol ${ }^{\circledR}$ (ethambutol: $600 \mathrm{mg} / \mathrm{d}$ ), Pyzina ${ }^{\circledR}$ (pyrazinamide: $750+500 \mathrm{mg} / \mathrm{d}$ ) every alternate day.

After 11 days of ATT (day-16 of hospitalisation), she started complaining of generalised muscle aches and knee pain. Physical examination revealed stiffness in the popliteal regions, calves, and arches of the feet on standing. Her SCr, SUA, and CK were measured and found to be $1.80 \mathrm{mg} / \mathrm{dL}, 12.6 \mathrm{mg} / \mathrm{dL}$, and 887
$\mathrm{U} / \mathrm{L}$, respectively. Despite treatment with febuxostat, SUA kept on rising $(13.1 \mathrm{mg} / \mathrm{dL})$ as shown in Table 1 . Her venous blood $(3 \mathrm{ml})$ was withdrawn every $2 \mathrm{hr}$ to estimate the plasma levels of first-line anti-tubercular drugs. The plasma concentrations were estimated using a simple and validated liquid chromatography-tandem mass spectrometry (LCMS/MS) in the Department of Pharmaceutical Chemistry, Poona College of Pharmacy, Pune, India, developed for simultaneous measurement of all the first-line antitubercular drugs. ${ }^{5}$

Suspecting drug-induced polyarthralgia and myopathy, pyrazinamide was discontinued and replaced with levofloxacin $500 \mathrm{mg} / \mathrm{d}$ as per NTEP guidelines. ${ }^{6}$ Febuxostat dose was increased to $80 \mathrm{mg} / \mathrm{d}$ and ibuprofen $400 \mathrm{mg} / \mathrm{d}$ for 5 days was added in her drug chart. After a week, her SUA and CK were measured and were found to be $9.3 \mathrm{mg} / \mathrm{dL}$ and $624 \mathrm{U} / \mathrm{L}$ (Table 1). She was afebrile. She was discharged from the hospital and continued with ATT except for pyrazinamide.

\section{Outcome and Follow-up}

One-month 18-days later, her polyarthralgia had settled completely. On examination, there was no focal muscle tenderness and her reflexes were normal. Her repeat SUA and CK levels had come down to $7.5 \mathrm{mg} / \mathrm{dL}$ and $386 \mathrm{U} / \mathrm{L}$ respectively (Table 1 ). She was asked to continue febuxostat with a tapered dose of $40 \mathrm{mg} / \mathrm{d}$ and was advised routine follow-up. The patient completed her intensive phase of ATT and is currently in the continuous phase of ATT with Akurit- $3 \circledR$ (rifampicin: $450 \mathrm{mg} / \mathrm{d}$, isoniazid: $300 \mathrm{mg} / \mathrm{d}$, ethambutol: $600 \mathrm{mg} / \mathrm{d}$ ). She had a good clinical response, and her ascites settled completely.

\section{DISCUSSION}

Dosage adjustment is an important therapeutic intervention in CKD patients receiving antitubercular therapy (ATT) as per creatinine clearance and body weight, particularly those who are on pyrazinamide and ethambutol. ${ }^{6,7}$ However, the associated outcomes of these dosage-adjustments in CKD patients have not been studied in detail. Similarly, the aftermaths associated with the occurrence of adverse effects and corresponding dose-adjustments are yet to be explored in the various stages of CKD. In our patient, pyrazinamide $1250 \mathrm{mg}$ on alternate days was prescribed compared to a normal kidney functioning (every-day) suspected TB patient. The guideline recommends that, depending upon the severity of the adverse reaction, therapy adjustments are needed. However, modifications should be performed 
Table 1: Lab Investigations performed during hospital stay.

\begin{tabular}{|c|c|c|c|}
\hline Parameters & $\begin{array}{c}\text { Baseline } \\
\text { (On admission) }\end{array}$ & Day 3 & Day 11 \\
\hline White blood cells & $5900 /$ cumm & $6000 /$ cumm & $3600 /$ cumm \\
\hline Serum creatinine & $1.6 \mathrm{mg} / \mathrm{dl}$ & $1.6 \mathrm{mg} / \mathrm{dl}$ & $1.8 \mathrm{mg} / \mathrm{dl}$ \\
\hline Serum albumin & $2.2 \mathrm{~g} / \mathrm{dl}$ & $2.8 \mathrm{~g} / \mathrm{dl}$ & $4.0 \mathrm{~g} / \mathrm{dl}$ \\
\hline Ascitic fluid analysis & Normal Range & Estimated & \\
\hline Proteins & $0.3-4.0 \mathrm{~g} / \mathrm{dL}$ & 6.31 & \\
\hline Glucose & $70-120 \mathrm{mg} / \mathrm{dL}$ & 71 & \\
\hline Lymphocytes & $<25 \%$ & 40 & \\
\hline ADA & $8.6-20.5 \mathrm{U} / \mathrm{L}$ & 35.7 & \\
\hline LDH & $140-280 \mathrm{U} / \mathrm{L}$ & 427 & \\
\hline SAAG & Clear & $<1.1$ Exudate) $^{*}$ & \\
\hline \multicolumn{4}{|c|}{ Pleural fluid analysis } \\
\hline - $\quad$ Proteins & $10-20 \mathrm{~g} / \mathrm{dL}$ & $7.0 \mathrm{~g} / \mathrm{dL}$ & \\
\hline - Glucose & $70-120 \mathrm{mg} / \mathrm{dL}$ & 89 & \\
\hline - Lymphocytes & $<25 \%$ & 50 & \\
\hline - $\quad A D A$ & $8.6-20.5 \mathrm{U} / \mathrm{L}$ & 56 & \\
\hline - $\quad \mathrm{LDH}$ & $140-280 \mathrm{U} / \mathrm{L}$ & 423 & \\
\hline - $\quad$ SAG & Clear & $>1.2(\text { Transudate })^{*}$ & \\
\hline \multicolumn{4}{|c|}{ Monitoring Laboratory Parameters } \\
\hline Time of onset ADR & \multicolumn{2}{|c|}{ 11th day post ATT } & \\
\hline \multicolumn{4}{|l|}{ Investigations } \\
\hline - $\quad$ Baseline & \multicolumn{2}{|c|}{ SUA - $7.2 \mathrm{mg} / \mathrm{dL} \quad \mathrm{CK}-156 \mathrm{U} / \mathrm{L}$} & \\
\hline - During the treatment & \multicolumn{2}{|c|}{ SUA - $12.6 \mathrm{mg} / \mathrm{dL}$ CK - $887 \mathrm{U} / \mathrm{L}$} & \\
\hline & \multicolumn{2}{|c|}{ SUA - $13.1 \mathrm{mg} / \mathrm{dL}$ CK - $792 \mathrm{U} / \mathrm{L}$} & \\
\hline - $\quad$ Post discontinuation & \multicolumn{2}{|c|}{ SUA - $9.3 \mathrm{mg} / \mathrm{dL} \quad$ CK $-624 \mathrm{U} / \mathrm{L}$} & \\
\hline - 1-month 18-days follow up & \multicolumn{2}{|c|}{ SUA $-7.5 \mathrm{mg} / \mathrm{dL} \quad \mathrm{CK}-386 \mathrm{U} / \mathrm{L}$} & \\
\hline \multicolumn{4}{|c|}{ C2h plasma levels of First line Anti-tubercular drugs } \\
\hline - Isoniazid & \multicolumn{2}{|c|}{$3.4 \mu \mathrm{g} / \mathrm{ml}$ (Normal range: $3-6 \mu \mathrm{g} / \mathrm{ml})$} & \\
\hline - $\quad$ Rifampicin & \multicolumn{2}{|c|}{$6.9 \mu \mathrm{g} / \mathrm{ml}$ (Normal range: $8-24 \mu \mathrm{g} / \mathrm{ml})$} & \\
\hline - $\quad$ Pyrazinamide & \multicolumn{2}{|c|}{$59 \mu \mathrm{g} / \mathrm{ml}$ (Normal range: $20-50 \mu \mathrm{g} / \mathrm{ml}$ ) } & \\
\hline - Ethambutol & \multicolumn{2}{|c|}{$2.3 \mu \mathrm{g} / \mathrm{ml}$ (Normal range: $2-6 \mu \mathrm{g} / \mathrm{ml})$} & \\
\hline
\end{tabular}

ADA - adenosine deaminase, LDH - lactate dehydrogenase, SAAG - serum ascites albumin gradient, SAG - serum-effusion albumin gradient, SUA - serum uric acid, CK -creatine kinase, ATT - anti-tubercular therapy ADR - adverse drug reaction, C2h: concentration at 2 hr.

* Implies tuberculosis

with suspected agents only, regimen change is not advised. ${ }^{6-8}$ In our patient, pyrazinamide was suspected of causing symmetrical polyarthralgia with joint effusion, which is evident from the subjective and objective assessments along with higher levels of $\mathrm{C} 2 \mathrm{~h}$ plasma concentration $(59 \mu \mathrm{g} / \mathrm{ml})$ beyond the normal range (Table 1). Therefore, it was replaced with levofloxacin. A pharmacokinetic study, ${ }^{9}$ on various dosing regimens of pyrazinamide proposed that serum pyrazinamide concentrations correlate closely with the pyrazinoic acid (POA) concentration in serum and urine at a POA/ pyrazinamide ratio of $1 / 3$. Authors also proposed that xanthine oxidase gets saturated at relatively low POA concentrations so that the longer the concentration persists above the threshold, the longer the maximal inhibition of xanthine oxidase, which leads to prolonged urate deposition in joints.

Once therapy stops, the concentrations fall and urate deposition stops, and the patients feel better. Rifampicin and pyrazinamide are reported to cause drug induced hepatitis and arthralgia/arthritis, respectively. CKD itself causes hyperuricemia and urate depositions, and in addition, patients receiving pyrazinamide are more prone to the development of associated adverse reactions, as seen in our patient despite alternate-day therapy. Hence, a careful watch is needed for at least the first 2-3 weeks of pyrazinamide initiation. ${ }^{6-8}$ The authors of 
a recent study, ${ }^{10}$ retrospectively examined and reported the incidence of drug-induced nephropathy and gout arthritis as $4.5 \%$ and $0.6-1.0 \%$, respectively, in patients with CKD. In our case, before initiation of ATT with pyrazinamide, the patient's estimated creatinine clearance (eCrCL) was $11.3 \mathrm{~mL} / \mathrm{min}$ (creatinine: $1.6 \mathrm{mg} / \mathrm{dL}$ ). On the day when she started complaining about knee and muscle pain, her eCrCL dropped to $10.04 \mathrm{~mL} / \mathrm{min}$ (creatinine: $1.8 \mathrm{mg} / \mathrm{dL}$ ). The suspected reaction could be drug-induced. The literature reports, creatinine $>2.0 \mathrm{mg} /$ $\mathrm{dL}$ in response to drug administration must be evaluated for drug-induced nephropathy. ${ }^{10}$ As per Naranjo's scale of ADR assesment, ${ }^{11}$ this case scored 8 out of 13 points, where a score of 5 to 8 indicates the "probable" association between pyrazinamide administration and the occurrence of polyarthralgia and myalgia.

\section{CONCLUSION}

Pyrazinamide should be used vigilantly in patients with renal impairment as they are more prone to get polyarthralgia and myalgia with short onset. Even in alternate-day therapy, pyrazinamide can induce polyarthralgia and symmetric joint pain. Pyrazinamide plasma levels may be an indicative of the adverse reaction.

\section{ACKNOWLEDGEMENT}

Authors want to express their gratitude to Department of Pulmonary Medicine, Bharati Vidyapeeth Medical College and Hospital, Pune, India for their support.

\section{CONFLICT OF INTEREST}

The authors declare no conflict of interest.

\section{ABBREVIATIONS}

CKD: chronic kidney disease; TB: tuberculosis; ATT: anti-tubercular therapy; TDM: therapeutic drug monitoring; USG: ultrasonography; 2D-ECHO: 2-dimentional echocardiography; LV: left ventricular; SAAG: serum ascites albumin gradient; SAG: serum- effusion albumin gradient; SCr: serum creatinine; SUA: serum uric acid; CK: creatine kinase; LCMS/ MS: liquid chromatography-tandem mass spectrometry; NTEP: national tuberculosis elimination program; C2h: concentration at 2 hr; POA: pyrazinoic acid; eCrCL: estimated creatinine clearance.

\section{Patient consent}

Verbal and written informed consent were taken from the patient for the publication of this case report.

\section{REFERENCES}

1. Stamatakis G, Montes C, Trouvin JH, Farinotti R, Fessi H, Kenouch S, Méry JP. Pyrazinamide and pyrazinoic acid pharmacokinetics in patients with chronic renal failure. Clin Nephrol. 1988;30(4):230-4. PMID 3214968.

2. Launay-Vacher V, Izzedine H, Deray G. Pharmacokinetic considerations in the treatment of tuberculosis in patients with renal failure. Clin Pharmacokinet. 2005;44(3):221-35. doi: 10.2165/00003088-200544030-00001, PMID 15762766.

3. Aronoff GR, Berns JS, Brier ME. Drug prescribing in renal failure: dosing guidelines for adults. 4th ed. Philadelphia: American College of Physicians; 1999.

4. Ellard GA. Chemotherapy of tuberculosis for patients with renal impairment. Nephron. 1993;64(2):169-81. doi: 10.1159/000187310, PMID 8321347.

5. Panda BK, Bargaje M, L S. A simple and reliable analytical method for simultaneous quantification of first line antitubercular drugs in human plasma by LCMS/MS. Anal Methods. 2020;12(31):3909-17. doi: 10.1039/d0ay00889c, PMID 32719834.

6. RNTCP national strategic plan for TB elimination in India. Central TB Division, DGHS. MOHFW, Government of India; 2017-2025. (Available from: https:// tbcindia.gov.in/WriteReadData/NSP\%20Draft\%2020.02.2017\%201.pdf.

7. World Health Organization. Treatment of tuberculosis [guidelines]. (Available from: https://www.ncbi.nlm.nih.gov/books/NBK138748/pdf/Bookshelf_ NBK138748.pdf. 4th ed. WHO/HTM/TB/2009.420). Geneva: WHO; 2010.

8. Nahid P, Dorman SE, Alipanah N, Barry PM, Brozek JL, Cattamanchi A, et al. Official American Thoracic Society/centers for disease control and prevention/ infectious diseases society of America clinical practice guidelines: treatment of drug-susceptible tuberculosis. Clin Infect Dis. 2016 Oct 1;63(7):e147-95. doi: 10.1093/cid/ciw376, PMID 27516382.

9. Ellard GA. Absorption, metabolism and excretion of pyrazinamide in man. Tubercle. 1969;50(2):144-58. doi: 10.1016/0041-3879(69)90020-8, PMID 5788407

10. Saito N, Yoshii Y, Kaneko Y, Nakashima A, Horikiri T, Saito Z, Watanabe S, Kinoshita A, Saito K, Kuwano K. Impact of renal function-based antituberculosis drug dosage adjustment on efficacy and safety outcomes in pulmonary tuberculosis complicated with chronic kidney disease. BMC Infect Dis. 2019;19(1):374. doi: 10.1186/s12879-019-4010-7, PMID 31046706.

11. Naranjo CA, Busto U, Sellers EM, Sandor P, Ruiz I, Roberts EA, Janecek E, Domecq C, Greenblatt DJ. A method for estimating the probability of adverse drug reactions. Clin Pharmacol Ther. 1981;30(2):239-45. doi: 10.1038/ clpt.1981.154, PMID 7249508. 